\title{
Evaluation of the Effectiveness of the Coagulation Process in the Treatment of Wastewater from the Foundry Industry
}

\author{
Paulina Dawczak ${ }^{1,2}$, Mariusz Dudziak²* \\ 1 Dempol-Eco, Składowa 9, 45-125 Opole, Poland \\ 2 Silesian University of Technology Institute of Water and Wastewater Engineering, Konarskiego 18, \\ 44-100 Gliwice, Poland \\ * Correponding author's e-mail: mariusz.dudziak@polsl.pl
}

\begin{abstract}
The wastewater from the foundry industry contains both inorganic and organic pollutants. Their characteristic feature is the variability of the composition, which depends on the intensity of production in a given industrial plant or the combination of various pollutant streams. As part of the paper, the coagulation process was proposed for the treatment of selected wastewater from the foundry industry. The purpose of the research was to evaluate the effectiveness of coagulation depending on the concentration of pollutants in wastewater.
\end{abstract}

Keywords: foundry industry, wastewater treatment, coagulation

\section{INTRODUCTION}

The foundry sector is one of the most dynamically developing branches of industry in the world. Since 2000, the global production of castings has increased by approx. $60 \%$. The foundry industry in Poland exhibited an upward trend, especially in the production of castings from nonferrous alloys, mainly aluminum. Poland is currently the fourth producer of this type of castings in Europe [Sobczak et al. 2016].

The main recipient of the foundry sector is the automotive industry [Huybrechts et al. 2018]. In recent years, one can observe an increase in the share of aluminum components in cars, such as power transmission components, engine blocks, cylinder heads, as well as body construction. It is caused by several factors, and above all the possibility of reducing the weight of the car, which directly translates into fuel consumption and emission of exhaust gases. The use of aluminum structural castings also enables to obtain a significant simplification of the body structure, and, by eliminating welds, also increase their strength [Łuszczak and Dańko 2013].
As a result of using modern casting technologies, including High Pressure Die Casting (HPDC) and Gravity Semi-Permanent Mold (GSPM) of aluminum elements, the following waste streams may be generated [European IPPC Bureau 2017]:

- solids: dust, used mass,

- polluted air: products of combustion and other reactions, suspended dust, pyrolysis and evaporation products,

- wastewater: inorganic compounds, organic compounds, metal dust,

- other.

It is assumed that the average amount of wastewater generated in the foundry is $0.5 \mathrm{~m}^{3} /$ tonne of castings [European IPPC Bureau 2017]. However, other wastewater streams may also be formed in the plant. Various physicochemical processes can be used for the treatment of wastewater from the foundry industry, including: coagulation, sedimentation, chemical precipitation, filtration, flotation, membrane processes, ion exchange or oxidation processes [Sobczak et al. 2016; Pang et al. 2016; Deng and Tikalsky 2006]. 
As part of the paper, for the treatment of selected wastewater from the foundry industry, the coagulation process was proposed. The purpose of the research was to evaluate the effectiveness of coagulation depending on the concentration of pollutants in wastewater.

\section{MATERIALS AND METHODS}

\section{Wastewater characteristics}

The research was carried out with the use of post-production wastewater collected in an industrial plant casting various aluminum components. The wastewater contained overheated hydraulic fluids, coolants and lubricants of foundry molds. They were collected after preliminary treatment in the process of flotation and sedimentation. The physicochemical characteristics of the wastewater are presented in Table 1. The wastewater was collected between September and November 2017.

The wastewater samples were characterized by a total suspended solids concentration of 220 to $410 \mathrm{mg} / \mathrm{L}$ and $\mathrm{BOD}_{5}$ and COD of $1400-1700$ $\mathrm{mgO}_{2} / \mathrm{L}$ and $6770-7055 \mathrm{mgO}_{2} / \mathrm{L}$, respectively. However, the concentration of non-ionic surfactants (NS) ranged from 195 to $280 \mathrm{mg} / \mathrm{L}$. Heavy metals and anions were also marked in the wastewater, but their concentrations were below the maximum allowable concentration determined when introducing the wastewater into the wastewater system of the local water company. The determined average ratio of $\mathrm{COD}$ to $\mathrm{BOD}_{5}$ over 2.5 indicates a high content of non-biodegradable substances in the tested wastewater.

Table 1. The physicochemical characteristics of the wastewater

\begin{tabular}{|l|c|c|}
\hline \multicolumn{1}{|c|}{ Parameter } & Unit & Value \\
\hline $\mathrm{pH}$ & - & $5,2-5,6$ \\
\hline Total suspended solids (TSS) & $\mathrm{mg} / \mathrm{L}$ & $220-410$ \\
\hline $\begin{array}{l}\text { Biochemical oxygen demand } \\
\left(\mathrm{BOD}_{5}\right)\end{array}$ & $\mathrm{mgO}_{2} / \mathrm{L}$ & $1400-1700$ \\
\hline Chemical oxygen demand (COD) & $\mathrm{mgO}_{2} / \mathrm{L}$ & $6770-7055$ \\
\hline Non-ionic surfactants (NS) & $\mathrm{mg} / \mathrm{L}$ & $195-280$ \\
\hline Copper $(\mathrm{Cu})$ & $\mathrm{mg} / \mathrm{L}$ & $0,05-0,23$ \\
\hline Zinc $(\mathrm{Zn})$ & $\mathrm{mg} / \mathrm{L}$ & $0,80-1,10$ \\
\hline Nickel $(\mathrm{Ni})$ & $\mathrm{mg} / \mathrm{L}$ & $<0,1$ \\
\hline Chlorides $\left(\mathrm{Cl}^{-}\right)$ & $\mathrm{mg} / \mathrm{L}$ & $40-90$ \\
\hline Sulfate $\left(\mathrm{SO}_{4}{ }^{2-}\right)$ & $\mathrm{mg} / \mathrm{L}$ & $35-64$ \\
\hline
\end{tabular}

Within the scope of the research, the treatment of the wastewater in question was also considered in the case of an additional stream of pollutants which is also generated in this industrial plant. It consisted of used baths from the sealing of aluminum castings, which had a COD value of approx. $100000 \mathrm{mgO}_{2} / \mathrm{L}$.

A laboratory CyberScan pH meter 1500 produced by Eutech Instruments was used to measure the $\mathrm{pH}$ of wastewater. The total suspension was determined with the weight method using MA 110.X2.A moisture balance (Radwag company). $\mathrm{BOD}_{5}$ was measured with a monometric method using OxiTop ${ }^{\circledR}$ (WTW) bottles. COD and NS were determined by spectrophotometry using a Spectroquant ${ }^{\circledR}$ Prove 300 spectrophotometer (Merck). The heavy metal concentration determinations were carried out using the method of flame atomic absorption spectrometry (FAAS) or atomic absorption spectrometry with electrothermal atomization (ET AAS) using contrAA ${ }^{\circledR} 700$ from Analytik Jena AG. On the other hand, in the determination of anions, the ion chromatography method (DionexTM ICS-1100 from Thermo ScientificTM) was used.

\section{Coagulation of wastewater}

The wastewater without and with the addition of used baths from the aluminum castings sealing department in the amount of $15 \mathrm{~mL} / \mathrm{L}, 30 \mathrm{~mL} / \mathrm{L}$ and $55 \mathrm{~mL} / \mathrm{L}$ was coagulated.

Highly alkaline pre-hydrolyzed Flokor $^{\circledR}$ 1.2A coagulant by Dempol-Eco was used for the wastewater coagulation process at a dose of 200 to $400 \mathrm{mg} / \mathrm{L}$. The wastewater coagulation process was carried out in a Velp Scientifica flocculator according to the modified "Jar-Test" procedure including fast mixing (100 rpm) for $1 \mathrm{~min}$, slow stirring $(40 \mathrm{rpm})$ for $5 \mathrm{~min}$ and sedimentation in $60 \mathrm{~min}$. The optimal dose of coagulant was selected as part of the study. The coagulation process was aided with Praestol 2515 polyelectrolyte from Solenis $(0.1 \%$ solution $)$ at a constant dose of $4 \mathrm{mg} / \mathrm{L}$. The $\mathrm{pH}$ of the wastewater was adjusted to pH 6.0-7.5 using $30 \% \mathrm{NaOH}$ solution.

\section{RESULTS AND DISCUSSION}

The optimal dose of coagulant chosen for wastewater without the addition of used baths was $300 \mathrm{mg} / \mathrm{L}$. This dose enabled to obtain colourless 
and clear wastewater and post-coagulation sediments with an extensive spatial structure. The physicochemical analysis of the supernatant liquid showed a high degree of reduction of the total suspended solids (approx. 83\%). COD of wastewater was decreased by approx. $42 \%$. In turn, the $\mathrm{NC}$ concentrations in wastewater before and after coagulation were at the same level.

Next, the effect of the addition of used baths to wastewater on the efficiency of the coagulation process was considered (Fig. 1).

The addition of used baths in the amount of $15 \mathrm{~mL} / \mathrm{L}$ did not change the effectiveness of wastewater coagulation. However, with the increased share of used baths in the wastewater, from 30 to $55 \mathrm{~mL} / \mathrm{L}$, deterioration of the process effectiveness was observed both in terms of their decolourisation and clarification, as well as lowering in the COD value. For example, the reduction of total suspended solids and COD of wastewater with the addition of $55 \mathrm{~mL} / \mathrm{L}$ of used baths was approx. $72 \%$ and $22 \%$. Correction of the coagulant dose had no effect on improving the effectiveness of the process.

\section{CONCLUSION}

High efficiency of the coagulation process in decolourisation and clarification of wastewater from the foundry industry was demonstrated. Wastewater coagulation also enables to lower the concentration of organic substances measured with the COD indicator. It does not affect the elimination of NS, which requires the use of additional wastewater treatment processes.

It was determined that the addition of an additional stream of pollutants to the wastewater may reduce the effectiveness of the coagulation process both in the aspect of their decolourisation and clarification, as well as lowering the COD value.

\section{Acknowledgements}

The work was carried out as part of the implementation doctorate funded by the Ministry of Science and Higher Education.

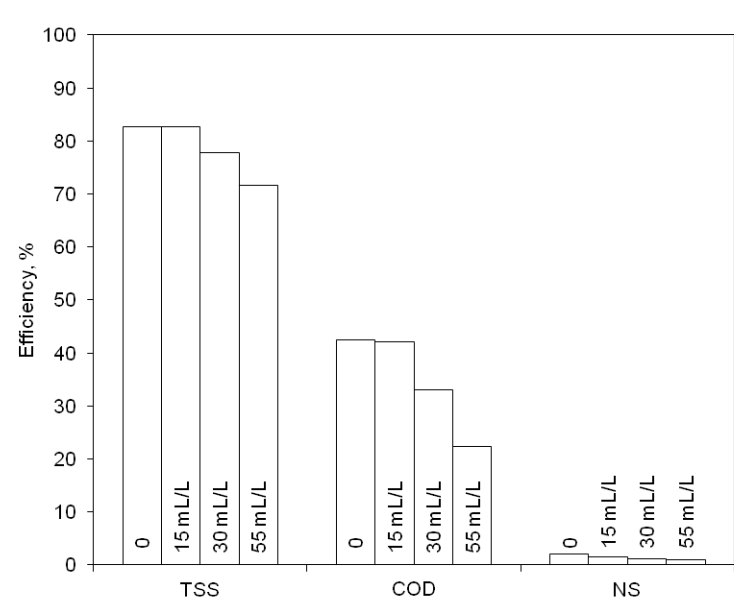

Figure 1. The efficiency of the coagulation process in treatment without and with the addition of used baths

\section{REFERENCES}

1. Deng A., Tikalsky P., 2006. Metallic characterization of foundry by-products per waste streams and leaching protocols. Journal of Environmental Engineering, 132, 586-595.

2. European IPPC Bureau - Institute for Prospective Technological Studies Sustainability in Industry, Energy and Transport, 2017. Best Available Techniques (BAT). Reference document on best available techniques (BAT) for non-ferrous metals industries. Industrial Emissions Directive 2010/75/ EU. Integrated Pollution Prevention and control.

3. Huybrechts D., Derden A., Van den Abeele L., Vander Aa S., Smets T., 2018. Best available techniques and the value chain perspective. Journal of Cleaner Production, 174, 847-856.

4. Łuszczak M., Dańko R., 2013. Stan zagadnienia w zakresie odlewania dużych odlewów strukturalnych ze stopów aluminium [The state of art of production of automotive structural die casted elements]. Archives of Foundry Engineering, 13, 113-116 (in Polish).

5. Pang T., Tao H., Ruan J.-B., Song A.-A., Song L., Liu Y., 2016. Investigation of water pollution in China's sand molding foundry industry. Zhuzao/ Foundry, 65, 40-44.

6. Sobczak J.J., Balcer E., Kryczek A., 2016. Sytuacja odlewnictwa w Polsce i na świecie - stan aktualny, tendencje, prognozy. [The situation of foundry in Poland and in the world - current status, trends and forecasts.]. Przegląd Odlewnictwa, 66, 106-115 (in Polish). 